The International Journal Of Engineering And Science (IJES)

|| Volume || 6 || Issue || 3 || Pages || PP 05-09 || 2017 ||

ISSN (e): $2319-1813$ ISSN (p): $2319-1805$

\title{
An Investigation of Errors Related to Solving Problems on Percentages
}

\author{
Duong Huu Tong \\ School of Education, Can Tho University, Vietnam
}

\begin{abstract}
-ABSTRACT
In primary schools of Viet Nam, solving problems on percentages is a very important bit of knowledge because it not only provides a full range of knowledge of percentages but also a lot of practical applications and has a great effect in the development of thinking for students. However, it is a kind of new and difficult problem, so students often commit errors to solve problems on percentages. A survey of 149 primary school students was done. The students had to answer 7 questions about the problems on percentages. Results show that they suffer some errors such as: misunderstanding kinds of problems, doing wrong calculation, confusing the units of measurements. At the end of the paper, some suggestions in mathematics education are made to teachers to support students avoiding errors in solving problems on percentages.
\end{abstract}

Keywords: Error, reason, solving problems on percentages, mathematics education.

Date of Submission: 02 March 2017

$\longrightarrow$ Date of Accepted: 27 March 2017

\section{INTRODUCTION}

Error topics usually attract great interest in academic theories. For example, the doctrine of behavior considers an error as a reflection of ignorance or negligence. Meanwhile, according to the constructivist theory, the error is an important factor in building the cognitive activity of students for some reasons. First, when creating an imbalance in the subject's thinking system, recognizing errors facilitates good conditions for students to overcome them and leads to a new incremental balance. Moreover, it is assumed that the error is not a minor event that occurs in a cognitive process. For this reason, it does not exist outside knowledge, but it is a reflection of knowledge.A French mathematical educator, Brousseau also emphasizes the importance of researching errors in teaching mathematics.

Errors are not only ambiguous or random things but also they are considered as the results of knowedge that has previously been found to be useful and successful, but now it is useless or unsuitable in new situations. These errors are not normal or unpredictable. They form obstacles. In teacher's activity as well as in student's activity, the errors always contribute to building the meaning of acquired knowledge.

(Brousseau, quoted in Bessot's book)

A Vietnamese mathematical educator, P.Đ. Thuc also shares the same point of view, and he says that correcting errors has an important significance in developing students' thinking, reinforcing their knowledge and skills. Futhermore, he thinks that the errors of students are due to many different reasons.

In addition to Thuc's view, the error was also studied by my colleague, Nguyen Phu Loc. He surveyed 12th grade students' errors in calculating the integrals in 2014 and solving problems on coordinate methods in space in 2015. Moreover, he raised some advantages of teachers' attention to students' errors such as: recognizing the errors of their students; adjusting their teaching methods; doing action research to check the effectiveness of their teaching. Solving problems on percentages is introduced in the 5th grade mathematics textbook of Vietnam. Besides, it is said to be a kind of exciting problem. Thus, to solve these problems, students must know how to analyze, synthesize and apply lots of learned knowledge to use that knowledge in a creative way. In fact, not all students solve the problems correctly, they also have many mistakes. For example, they still apply the wrong rule to find the percentages of the two numbers. Here, to better understand this, we clarify three basic kinds of percentage problems and ways to solve them.

\section{Kind 1: Find the percentages of the two numbers}

Example: There are 315 schoolgirls in Van Tho Primary School out of all 600 students. Find the percentage of schoolgirls.

Solution:

The ratio of schoolgirls to all students in the school is $315: 600$. We have:

$315: 600=0.525$

$0.525 \times 100: 100=52.5: 100=52.5 \%$ 
So the percentage of schoolgirls is $52.5 \%$.

A process of solving this problem:

To find the percentage of 315 to 600 , we do the following steps:

- Find the quotient when dividing 315 by 600.

- Multiply the found quotient by 100 and add the symbol "\%" to the right of the product.

Kind 2: Find the percentage value of a number

Example: A primary school has 800 students, $52.5 \%$ of which are schoolgirls. How many schoolgirls are there in that school?

Solution:

$1 \%$ of students of the whole school is: $800: 100=8$ (students)

The number of schoolgirls or $52.5 \%$ of all students is: $8 \times 52.5=420$ (students)

The textbook mentions a rule: To find $52.5 \%$ of 800 , we divide 800 by 100 then multiply the quotient by 52.5 , or multiply 800 by 52.5 then divide the product by 100 .

Kind 3: Find a number knowing its percentage

Example: There are 420 girls in a school, who account for $52.5 \%$ of all students. How many students are there in the school?

Solution:

$1 \%$ of all students are: $420: 52.5=8$ (students)

The total number of students in the school or $100 \%$ students of the schoool are: $8 \times 100=800$ (students)

Those steps can be merged as: $420: 52.5 \times 100=800$

A solving rule is raised in the textbook: To find a number knowing that $52.5 \%$ of it is 420, we divide 420 by $52.5 \%$ then multiply the quotient by 100 or multiply 420 by 100 then divide the product by 52.5 .

The process of solving the above problems is rather complex. In addition, students must usually manipulate on decimals. Also, their practical skills needed in analyzing and synthesizing diagrams and tables, and establishing the relationship between the data in the percentage problems are limited almost. Therefore, it is inevitable for students to commit errors to solve these kinds of problems.

The research question: Do students have errors in solving the problems on percentages? Which errors can they commit?

\subsection{Participants}

\section{METHODOLOGY}

The experiment was conducted in four classes in Ngo Quyen Primary School in Cantho city, Vietnam. There were all 149 th grade students. They are eleven years old.

2.2. Instrument and procedure

Students have to answer 7 objective questions. These test types are true-false and multiple choices.

The student questionnaire

You just circle the correct answer

1. To find the percentage of 13 out of 25 , we have to do:
A. $25: 13$
B. $13: 25$
C. $25: 38$
D. $13: 38$

2. To find the percentage of 1 out of 6 knowing $1: 6=0.166666 \ldots$ The percentage of 1 out of 6 is:
A. $16 \%$
B. $16.66 \%$
C. $17 \%$
D. All of them are correct.

3 . There are $2.8 \mathrm{~kg}$ of salt in $80 \mathrm{~kg}$ of sea water. Find the percentage of salt to sea water.

The following solution is true or false?

Solution

The percentage of salt to sea water is:

$2.8: 80=0.035 \%$

Answer: $0.035 \%$

A. True B. False

4. $0.07 \%=$
A. $\frac{7}{10}$
B. $\frac{7}{100}$
C. $\frac{7}{1000}$
D. $\frac{7}{10000}$

5. Find $10 \%$ of $8 \mathrm{dm}$ :
A. $8 \mathrm{~cm}$
B. 0.8
C. Both of A and B are correct
D. Both of A and B are wrong

6.

a. Find $30 \%$ of 72 . Choose the correct calculation
A. $72 \times 30: 100=21.6$
B. $72: 30 \times 100=240$
C. $30: 72 \times 100=41.67$

b. Find a number of which $30 \%$ is 72 . Choose the correct calculation 

A. $72 \times 30: 100=21.6$
B. $72: 30 \times 100=240$
C. $30: 72 \times 100=41.67$

7. A primary school has 600 students, $52 \%$ of which are schoolgirls. How many schoolgirls are there in that school?

The following solution is true or false?

Solution

$1 \%$ of students of the whole school is: $600: 100 \%=6$ (students)

The number of schoolgirls is: $6 \times 52 \%=312$ (students)

Answer: 312 students.
A. True
B. False

a. The class context of the experimental questions

Students learnt three kinds of problems on percentages. The methods of solving them were specifically introduced to students by their teachers.

$b$. The corrcect answers expected for questions in the context of Vietnam

The right answers to the given questions were presented in Table 1.

Table 1: The correct answers expected to 8 questions

\begin{tabular}{|l|l|l|l|l|l|l|l|l|}
\hline Questions & $\mathbf{1}$ & $\mathbf{2}$ & $\mathbf{3}$ & $\mathbf{4}$ & $\mathbf{5}$ & $\mathbf{6 a}$ & $\mathbf{6 b}$ & $\mathbf{7}$ \\
\hline Answers & $\mathbf{B}$ & $\mathbf{B}$ & $\mathbf{B}$ & $\mathbf{D}$ & $\mathbf{A}$ & $\mathbf{A}$ & $\mathbf{B}$ & $\mathbf{B}$ \\
\hline
\end{tabular}

III. RESULTS AND DISCUSSION

Table 2: The percentages of students choosing the answers

\begin{tabular}{|l|l|l|l|l|}
\hline Questions & A & B & C & D \\
\hline $\mathbf{1}$ & $11(7.38 \%)$ & $131(87.92 \%)$ & $3(2.01 \%)$ & $4(4.03 \%)$ \\
\hline $\mathbf{2}$ & $19(12.75 \%)$ & $123(82.55 \%)$ & $0(0.00 \%)$ & $7(4.70 \%)$ \\
\hline $\mathbf{3}$ & $35(23.49 \%)$ & $114(76.51 \%)$ & & \\
\hline $\mathbf{4}$ & $4(2.68 \%)$ & $121(81.21 \%)$ & $2(1.34 \%)$ & $32(8.05 \%)$ \\
\hline $\mathbf{5}$ & $36(24.16 \%)$ & $36(24.16 \%)$ & $21(14.09 \%)$ & $56(37.58 \%)$ \\
\hline $\mathbf{6 a}$ & $122(81.88 \%)$ & $13(8.72 \%)$ & $14(9.40 \%)$ & \\
\hline $\mathbf{6 b}$ & $26(17.45 \%)$ & $117(78.52 \%)$ & $6(4.03 \%)$ & \\
\hline $\mathbf{7}$ & $129(86.58 \%)$ & $20(14.42 \%)$ & & \\
\hline
\end{tabular}

Question 1: This question was used to check students' ability to find the percentage of the two numbers. Specifically, did they really find the quotient of the two numbers corrcectly?. From the survey results, $87.92 \%$ of students chose the right result (B). However, 18 students were still confused. The reason was that they did not distinguish between the object to compare and the object selected as a comparison unit.

Question 2: When finding the percentage of two numbers and the quotient was a infinite remainder, $17.45 \%$ of students got the wrong results. They also calculated wrongly due to lack of knowledge. Students forgot that when they found the percentage, the result had to be a four-figure decimal.

Question 3: To find the percentage of the two numbers, students will go through two steps. The first step is finding the quotient of the two numbers. The other step is multiplying the found quotient by 100 and adding the symbol "\%" to the right of the product. However, according to the survey, up to $23.49 \%$ of students were confused when calculating this form of problem, because they were subjective or careless while doing the homework. Some children missed the step of multiplying the quotien by 100 , in particular, they only found the quotient, then added the symbol "\%" to the right of the quotient. It led to wrong results.

Question 4: According to Table 2, the correct answer of the fourth question was D, but only $8.05 \%$ of students chose this answer. That proves that the majority of students made the mistake of writing the percentage into decimal fractions. The children calculated incorrectly because they confused this kind of problem with the problem "writing a decimal into a decimal fraction". Meanwhile, some children's calculation skills were limited to find the exact result.

Question 5: When finding a percentage value of a number with a unit attached (maybe $\mathrm{cm}, \mathrm{dm}, \mathrm{kg}, \mathrm{g}, \ldots$ ), only $24.16 \%$ of students identified the correct result. The remaining children found the wrong result due to forgetting the accompanying unit behind it. Also, some children knew that there were units attached but in the answers there were no units like the given question, they chose the answer D "Both of A and B are wrong". Nevertheless, the unit was calculated, transferred to another unit, and the result was still true. It revealed that students were absent-minded while doing their homework. 
Questions 6a and 6b: The percentages of correct answers were respectively $81.88 \%$ in question $6 \mathrm{a}$ and $78.52 \%$ in question $6 \mathrm{~b}$. It was clear to say that students also made the mistakes of solving problems "find the percentage value of a number" and "find a number knowing its percentage". The main reason was due to students" confusion between their solutions. Indeed, some children have a habit of mechanically remembering, for example, one will multiply by 100 and the other will divide by 100 . Because they did not understand the nature of the problems, they applied the rules wrongly. If the students do not master the knowledge, it is easy for them to have errors in new situations.

Question 7: From the results of the survey, $86.58 \%$ of students made mistakes as they did not understand the nature and meaning of the "\%" symbol. In this case, they found the right result, but they misrepresented. By way of consequences, they was indiscriminate in using the "\%" symbol, leading to a mathematical misnomer. One more thing is that because they are absent-minded during the test, when they found the result " 312 ", similar to the result of the answer they was not interested in the presentation. Only a small number of students $(14.42 \%-$ B) were careful to do the right choice. A student's work is presented below:

Trường: Tiểu học Ngô Quyền

Lớp: .........5.

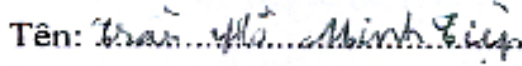

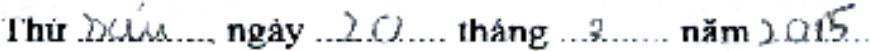

\section{PHIÊU KHẢO SÁT HỌC SINH}

\section{Em hãy khounh tròn vào câu trả lởi đúng}

Câu 1: Khi thực hiện tinh tí số phà̀n trãm của hai số 13 và 25 . Ơ bước thử nhất, tìm thương cùa hai số, eàch xảe định nào đúng:
A. $25: 13$
(B) $13: 25$
C. $25: 38$
D. $13: 38$

Câu 2: Tìm tỉ số phần trằm của hai số 1 và 6 . Biết 1 : $6=0,166 G G G 6 \ldots . . . .$. Tỉ số phần trăm của 1 và 6 là:
A. $16 \%$
B. $16,66 \%$
C. $17 \%$
D. Cà $\mathrm{A}, \mathrm{B}, \mathrm{C}$ dều dúng

Cầu 3: Trong 80kg nước biển có chứa $2,8 \mathrm{~kg}$ muối. Tìm tỉ số phần trăm của lượng muối trong nước biển.

Bài giải duơơ đây dúng hay sai ?

Tì số phần trăm cùa lượng muối trong nược biè̀n là:

$$
\begin{gathered}
2.8: 80=0.035 \% \\
\text { Đ/s : } 0.035 \%
\end{gathered}
$$
A. Đưng
(B) Sai

Câu 4: $0,07 \%=$
A. $\frac{7}{10}$
(B) $\frac{7}{100}$
C. $\frac{7}{1000}$
D. $\frac{7}{10000}$

Câu 5: Tim 10\% cüa $8 \mathrm{dm}$ là
A. $8 \mathrm{~cm}$
(B) 0.8
C. Cả $\mathrm{A}, \mathrm{B}$ dểu dúng
D. Cá $A, B$ đều sai 


\section{Câu 6: Chọn phép tính đúng}

\begin{tabular}{|c|c|}
\hline a) Tìm $30 \%$ của 72 & b) Tìm một số biết $30 \%$ của nó là 72 \\
\hline A. $72 \times 30: 100=21,6$ & A. $72 \times 30: 100=21,6$ \\
\hline B. $72: 30 \times 100=240$ & (B). $72: 30 \times 100=240$ \\
\hline C. $30: 72 \times 100=41,67$ & C. $30: 72 \times 100=41,67$ \\
\hline
\end{tabular}

\section{Câu 7: Một trường tiểu học có 600 HS. Trong đó số HS nữ chiếm 52\%. Tính số HS nữ?}

Bài giải sau đúng hay sai?

$1 \%$ số HS toàn trường là: $600: 100 \%=6(\mathrm{HS})$

Số HS nữ là: 6 × 52\% = $312(\mathrm{HS})$

Đ/s: $312 \mathrm{HS}$
A. Đúng
B. Sai

\section{Chúc các em chăm ngoan, học giỏi!}

\section{CONCLUSION}

The survey results show that many students make the mistakes of solving the problem on percentages. Additionally, the causes of the errors are also varied. The sstudents may be careless, misunderstand the problems or do not still discriminate among the kinds of problems on percentages. Therefore, it is important to say that the teachers should know the errors and find their causes so that they need to take practical measures to help their students overcome such errors. The necessities in mathematics education that teachers must pay attention to during instruction to help students learn the percentage well are:

- Combining teaching methods with proficient use of teaching media.

- Paying attention to the basic knowledge when teaching new lessons.

- Practicing step by step clearly, specifically, do not turn off the steps when practicing the sample.

- Carefully analyzing the causes of the errors to correct promptly, then let students do the same exercises.

- Appreciating the method of practice in teaching the problems on percentages in elementary schools.

\section{REFERENCES}

[1]. Bessot, A., Comiti, C., Chau, L.T.H., Tien, L.V.,(2009). The fundamental elements of Mathematics Didactic, Ho Chi Minh city: Publishing house of The national university of Ho Chi Minh.

[2]. Hoan, Đ. Đ (editor). (2007). Mathematics 5 (Toán 5), Hanoi: Publishing house of Education.

[3]. Loc, N. P. \& Hoc, T.C.T. (2014).A Survey of 12th Grade Students' Errors in Solving Calculus Problems. International Journal of Scientific \& Technology Research, Volume 3, Issue 6, June 2014 ISSN 2277-8616.

[4]. Loc, N.P. \& Kha, N.T. (2015). Students' errors in solving problems on coordinate methods in space: Results from an investigation in Vietnam, European Academic Research, Vol.III, and Issue 2/May.

[5]. Thuc, P.Đ. (2009). Methods of teaching mathematics in primary schools, Hanoi: Publishing house of Education. 